\title{
EfFect of Ecological Factors on Germination of HoRse PuRslane (Trianthema portulacastrum) ${ }^{1}$
}

\author{
Efeito de Fatores Ecológicos na Germinação de (Trianthema Portulacastrum)
}

\author{
TANVEER. A. ${ }^{2}$, MUMTAZ. K. ${ }^{2}$, JAVAID, M.M. ${ }^{3 *}$, CHAUDHRY, M.N. ${ }^{4}$, BALAL, R.M. ${ }^{5}$, and \\ KHALIQ, A. ${ }^{2}$
}

\begin{abstract}
Trianthema portulacastrum is a very problematic summer crop weed and a complete crop failure has been observed because of this weed at high density. The effect of different ecological factors on germination of T. portulacastrum seeds collected in two different years (2009 and 2005) was studied in laboratory experiments. An increase in temperature from 25 to $35{ }^{\circ} \mathrm{C}$ increased germination percentage of T. portulacastrum from 65 to $85 \%$, after which germination started to decrease, reducing to $71.25 \%$ at $45{ }^{\circ} \mathrm{C}$. Trianthema portulacastrum had maximum germination with distilled water compared with different salt solutions and drought stress levels. Germination was significantly minimum at salinity and drought stress level of $250 \mathrm{mM}$ and $-0.8 \mathrm{MPa}$, respectively. Emergence of T. portulacastrum was maximum $(86.25 \%)$ at $100 \%$ field capacity level but decreased sharply as field capacity decreased thereafter, and minimum emergence $(30 \%)$ was recorded at field capacity level of $25 \%$. Germination of T. portulacastrum was lowest at $\mathrm{pH} 5$ and any increase in $\mathrm{pH}$ resulted in increased germination. A pH range of 8 to 10 had statistically similar germination. Sowing depth of $6 \mathrm{~cm}$ reduced the emergence of $T$. portulacastrum to zero. Reduction in emergence was recorded with depth increase from zero to $5 \mathrm{~cm}$. Maximum emergence was recorded from soil surface $(0 \mathrm{~cm})$. An increase in temperature, salinity, drought, sowing depth (up to $4 \mathrm{~cm}$ ) and a decrease in field capacity increased time to start germination/emergence, time to $50 \%$ germination/emergence and mean germination/emergence time but decreased germination/emergence index. Seeds collected during 2009 gave higher germination than old seeds collected in 2005 . This information might contribute to development of effective control of T. portulacastrum.
\end{abstract}

Keywords: temperature, drought stress, salt stress, field capacity, $\mathrm{pH}$, sowing depth.

RESUMO - Trianthema portulacastrum é uma planta daninha bastante problemática para safras de verão, e observa-se a perda total de safras por causa da alta densidade desta planta daninha. Em experimentos de laboratório, foi investigado o efeito de diferentes fatores ecológicos sobre a germinação de sementes de $\boldsymbol{T}$. portulacastrum coletadas em dois anos diferentes (2009 e 2005). O aumento da temperatura de 25 para $35^{\circ} \mathrm{C}$ elevou a percentagem de germinação de T. portulacastrum de 65 para $85 \%$, a qual, em seguida, foi reduzi da para 71,25\% à temperatura de $45^{\circ} \mathrm{C}$. A máxima germinação de Trianthema portulacastrum ocorreu com água destilada, em comparação com soluções salinas e níveis de estresse hídrico diferentes. A germinação foi significativamente minima com niveis de estresse salino e hidrico de $250 \mathrm{mM}$ e -0,8 MPa, respectivamente. A emergência máxima (86,25\%) ocorreu a 100\% do nivel de capacidade de campo, mas diminuiu drasticamente à medida que a capacidade de campo foi reduzida, e a emergência minima (30\%) foi registrada no nivel de $25 \%$ da capacidade de campo. A menor germinação de T. portulacastrum foi observada com $\mathrm{pH}$ 5, e o aumento no $\mathrm{pH}$ resultou em uma maior taxa de germinação. A germinação teve indices estatisticos semelhantes quando o pH variou entre 8 e 10 . A profundidade da semeadura de $6 \mathrm{~cm}$ reduziu a emergência de T. portulacastrum a zero. Foi observada a redução da emergência com o aumento da profundidade de zero para $5 \mathrm{~cm}$. A emergência

Recebido para publicação em 18.9.2012 e aprovado em 18.2.2013.

2 Department of Agronomy, University of Agriculture Faisalabad, 38040, Pakistan; ${ }^{3}$ Department of Agronomy, University College of Agriculture, University of Sargodha, 40100, Pakistan, *Corresponding author <mmansoorjavaid@gmail.com>; ${ }^{4}$ University College of Agriculture and Environmental Sciences, The Islamia University of Bahawalpur, Pakistan; ${ }^{5}$ Department of Horticulture, University College of Agriculture, University of Sargodha, 40100, Pakistan 
máxima foi registrada a partir da superficie do solo $(0 \mathrm{~cm})$. O aumento de temperatura, salinidade, estresse hídrico, profundidade de semeadura (até $4 \mathrm{~cm}$ ) e a diminuição da capacidade de campo aumentaram o tempo para iniciar a germinação/emergência, otempo de 50\% de germinação/emergência etempo médio de germinação/emergência, mas o indice de germinação/emergência foi reduzido. As sementes coletadas em 2009 resultaram em maior germinação do que as sementes antigas, colhidas em 2005. O conhecimento destas informações pode ajudar no desenvolvimento de um controle eficaz de $T$. portulacastrum.

Palavras-chave: temperatura, estresse hídrico, estresse salino, capacidade de campo, $\mathrm{pH}$, profundidade de semeadura.

\section{INTRODUCTION}

Horse purslane (Trianthema portulacastrum) belongs to the Aizoaceae family and is a much branched, fast growing, prostrate, succulent annual herb with ovate green leaves. Horse purslane is indigenous to South Africa, but it is widely distributed in India, Pakistan, Sri Lanka, West Asia, Africa, and tropical America (Saeed et al., 2010). It is a weed of cultivated fields and waste lands. It grows luxuriantly if water is available and it is especially problematic in maize, cotton, potato, sugarcane, pulses, fodders and vegetables, particularly during rainy season (Hazra et al., 2011). Its prostrate growth and profuse branching capacity helps it to quickly cover the soil surface and form a green carpet (Senthil et al., 2009). It has exclusively vegetative growth for a short time period of 35-40 days after emergence and then both vegetative growth and reproductive growth continue simultaneously (Das, 2008). It produces numerous small, white flowers from April to October in Pakistan, and it has high fecundity. At its high density, complete crop failure has been observed in the farmer's fields.

Several studies have reported that seed germination and seedling emergence of a species are influenced by factors such as seed age, $\mathrm{pH}$, temperature, moisture, salinity and sowing depth (Chachalis \& Reddy, 2000; Hossain et al., 2001; Kaya et al., 2006; Jamil et al., 2007). Salinity causes considerable decline in germination percentage and seedling growth by specific ion toxicity and osmotic effect (Taisan, 2010). The level of drought and salinity at which germination is reduced varies with species, genotype, environmental conditions, osmotic potential and specific ions (Ungar, 1991). Acidity and alkalinity have a significant effect on germination of weeds (Ramirez et al., 2012). Seed burial depth and amount of food reserve in seeds are considered important factors that affect weeds emergence under soil (Nandula et al., 2006) by affecting temperature, light and water supply (Rao et al., 2008).

The study of seed germination ecology plays an important role in checking the potential of weeds to grow under different agroecological conditions and in developing better management strategies for weed control. A previous study was conducted by Balyan $\&$ Bhan (1986) on germination of $T$. portulacastrum under different temperature and seeding depth, but no research has been done on other environmental factors. Therefore, the objective of this study was to determine the effect of temperature, salinity, drought stress, field capacity, $\mathrm{pH}$ and sowing depth on germination of $T$. portulacastrum seeds collected in two different years.

\section{MATERIALS AND METHODS}

Seed Description and Germination Test: Trianthema portulacastrum seeds were collected at maturity from non-cropped areas in the Ayub Agricultural Research Institute, Faisalabad, Pakistan in the years 2005 and 2009. Seeds were cleaned and dried for 7 days at room temperature and then stored in paper bags in laboratory at room temperature until further use. The study was carried out in the laboratory of the Department of Agronomy, University of Agriculture, Faisalabad, Pakistan.

Germination was determined by evenly placing 25 seeds in a $9 \mathrm{~cm}$ diameter Petri plate containing Whatman filter paper No. 10, 
moistened with $5 \mathrm{ml}$ distilled water or a treatment solution. Seeds of $T$. portulacastrum were surface-sterilized by soaking in 10\% sodium hypochlorite $(\mathrm{NaOCl})$ for $5 \mathrm{~min}$, followed by five rinses with distilled water before the start of each germination trial. The Petri plates were sealed with Parafilm to reduce water loss. All the experiments (except for the temperature experiment) were conducted at $35^{\circ} \mathrm{C}$ with a $10 \mathrm{~h}$ photoperiod. Germinated seeds with a radicle at least $2 \mathrm{~mm}$ long were counted and removed daily for a period of 2 wk.

Effect of Temperature: Germination was determined in growth chambers under constant temperatures of $25,30,35,40$, and $45{ }^{\circ} \mathrm{C}$. These temperatures were selected because this weed grows from April to October in Pakistan and the temperature during this period ranges from 25 to $45^{\circ} \mathrm{C}$.

Effect of pH: Solutions with pH 5, 6, 7, 8, 9 and 10 were prepared using three buffer solutions. A 2-mM solution of MES [2-(Nmorpholino) ethanesulfonic acid] was adjusted to $\mathrm{pH} 5$ or 6 with $1 \mathrm{~N} \mathrm{NaOH}$. A 2-mM solution of HEPES [N-(2-hydroxy-methyl)piperazine-N-(2ethanesulfonic acid)] was adjusted to $\mathrm{pH} 7$ or 8 with $1 \mathrm{~N} \mathrm{NaOH}$. A pH 9 or 10 buffer was prepared with $2-\mathrm{mM}$ tricine [N-tris (hydroxymethyl) methylglycine] and adjusted with $1 \mathrm{~N} \mathrm{NaOH}$ (Chachalis \& Reddy, 2000). These $\mathrm{pH}$ levels were selected because of the nature of Pakistan soil in which pH is mostly above 7 .

Drought Stress: Aqueous solutions with osmotic potential of 0 (distilled water/control), $-0.2,-0.4,-0.6$ and $-0.8 \mathrm{MPa}$ were prepared by dissolving appropriate amounts of polyethylene glycol (PEG) 6000 in deionized water (Steuter et al., 1981).

Salt Stress: Sodium chloride solutions of 0 (distilled water), 25, 50, 75, 100, 125,150, 175, 200, 225 and $250 \mathrm{mM}$ were prepared. Salinity levels were selected because of higher salt concentration in Pakistan soils.

Field capacity: To study emergence under 25, 50,75 and $100 \%$ field capacity levels, saturated soil paste was prepared using distilled water. Half of the water used in making the paste was considered as $100 \%$ field capacity. Similarly, 25, 50 and $75 \%$ field capacity levels were maintained. Twenty five seeds were sown in $5 \mathrm{~kg}$ soil-filled pots.

Sowing depth: Ten seeds of $T$. portulacastrum were placed in plastic pots filled with $0.5 \mathrm{~kg}$ sand at $0,1,2,3,4,5$, and $6 \mathrm{~cm}$ depths. Initially, $100 \mathrm{ml}$ distilled water was added to each pot and, after that, water was applied whenever needed. These pots were placed in the laboratory at $35^{\circ} \mathrm{C}$.

The time to obtain $50 \%$ germination or emergence $\left(T_{50}\right.$ or $\left.E_{50}\right)$ was calculated according to the following formula of Coolbear et al. (1984):

$$
T_{50} \text { or } E_{50}=t_{i}+\frac{\left(\frac{N}{2}-n_{i}\right)\left(t_{j}-t_{i}\right)}{\left(n_{j}-n_{i}\right)}
$$

where $N$ is the final number of germinated or emerged seeds and $n_{j}$ and $n_{i}$ are the cumulative number of seeds germinated by adjacent counts at times $t_{j}$ (day) and $t_{i}$, (day) respectively, when $n_{i}<\mathrm{N} / 2<n_{j}$.

Mean germination/emergence time ( $M G T$ or $M E T)$ was calculated according to the equation of Ellis \& Roberts (1981):

$$
M G T \text { or } M E T=\frac{\sum D n}{\sum n}
$$

where $n$ is the number of seeds that had germinated on day $D$ and $D$ is the number of days counted from the beginning of germination. The germination/emergence index (GI or EI) was calculated as described by the Association of Official Seed Analysis (AOSA, 1983) using the following formula:

$$
\begin{aligned}
\text { GI or EI } & =\frac{\text { No of germinated } \text { or emerged seeds }}{\text { Days of first count }}+\ldots . . \\
& +\frac{\text { No of germinated } \text { or emerged seeds }}{\text { Days of final count }}
\end{aligned}
$$

\section{Statistical analysis}

A completely randomized design with four replications was used in all experiments. Except for the experiments of germination percentage of $T$. portulacastrum in salt and osmotic stress and the experiments of 
T. portulacastrum emergence percentage in burial depth and field capacity, all data were subjected to analysis of variance (ANOVA) with the use of SAS (2002). When a significant difference was found by ANOVA at 5\% level of probability, the treatments were identified using Fisher's LSD (Steel et al., 1997). A square-root arcsine transformation was used to stabilize the variances for percentage data before analysis (Bartlett, 1947). Nonlinear regression analysis was used to determine how $\mathrm{NaCl}$, osmotic stress, burial depth or field capacity affected percentage of germination or emergence. Germination (\%) values at different concentrations of $\mathrm{NaCl}$ and osmotic potential were fitted to a functional threeparameter logistic model using Sigma Plot 2008 (version 11.0). The model fitted was $G(\%)=G_{\max } /\left[1+\left(x / x_{50}\right)^{\text {Grate }}\right]$, where $G$ is total germination $(\%)$ at concentration or osmotic potential $x, G_{\max }$ is maximum germination (\%), $x_{50}$ is $\mathrm{NaCl}$ concentration or osmotic potential for $50 \%$ inhibition of maximum germination and $G_{\text {rate }}$ indicates the slope. A three-parameter logistic model $\left\{E(\%)=E_{\text {max }} /\left[1+\left(x / x_{50}\right)^{E}\right.\right.$ rate $\left.]\right\}$ was fitted to the $T$. portulacastrum seedling emergence $(\%)$ obtained at different burial depth of 0 to $10 \mathrm{~cm}$ and field capacity of 100 to $25 \%$ where $E$ is total seedling emergence (\%) at burial depth of field capacity $x, E_{\max }$ is maximum seedling emergence $(\%), x_{50}$ is burial depth of field capacity for $50 \%$ inhibition of maximum seedling emergence and $E_{\text {rate }}$ indicates the slope.

\section{RESULTS AND DISCUSSION}

Effect of temperature: Figure 1A shows the germination percentage of one-year-old and five-year-old $T$. portulacastrum seeds affected by different temperatures. Maximum germination of both types of seeds was
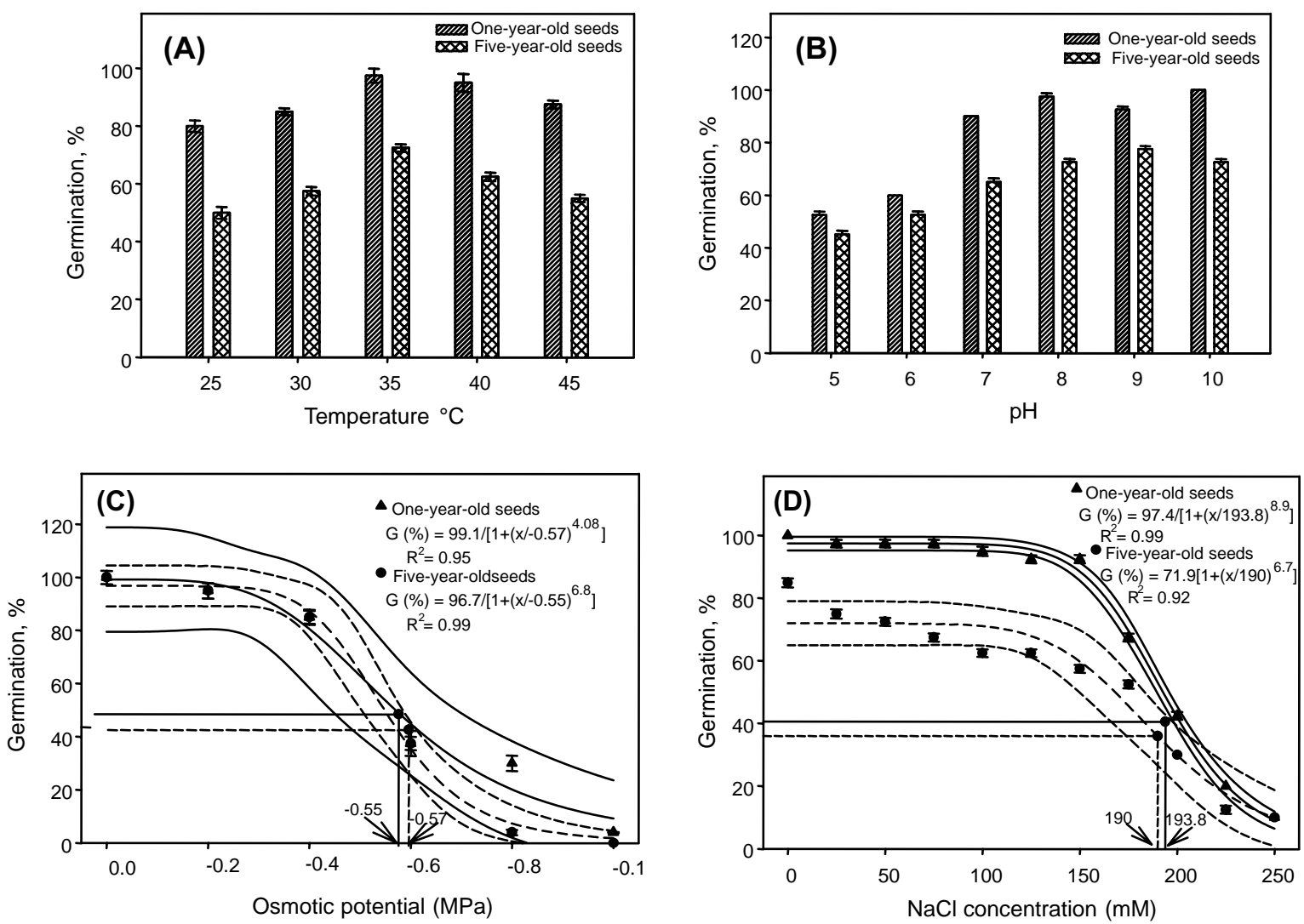

Figure 1 - Effect of temperature (A), pH(B), osmotic potential (C) $\mathrm{NaCl}$ concentration (D) on germination of T. portulacastrum. For Figures $\mathrm{C}$ and $\mathrm{D}$, bold lines represent a three-parameter logistic model fitted to the data for T. portulacastru, and thin lines show 95\% confidence intervals. Continuous lines (__ $)$ are used for one-year-old seeds and dash lines (- - - -) for five-year-old seeds. Vertical lines represent \pm standard error of the mean if greater than the size of symbol. 
recorded at $35{ }^{\circ} \mathrm{C}$ temperature. An increase in temperature from 25 to $35^{\circ} \mathrm{C}$ increased germination percentage from 65 to $85 \%$. After $35{ }^{\circ} \mathrm{C}$, germination started to decrease and was reduced to $71.25 \%$ at $45{ }^{\circ} \mathrm{C}$. Time to start germination, time to $50 \%$ germination and mean germination time were lower in oneyear-old seeds than five-year-old seeds (Table 1). Minimum time to start germination $(1.00 \mathrm{~d})$, time to $50 \%$ germination $(1.30 \mathrm{~d})$ and mean germination time (1.99 d) were observed at $40{ }^{\circ} \mathrm{C}$ (Table 1). Maximum germination index (8.21) was found at $40{ }^{\circ} \mathrm{C}$. This study concluded that an increase in temperature increased germination of $T$. portulacastrum. It is presumed that metabolic activities initiating germination were higher at 35 and $40{ }^{\circ} \mathrm{C}$. Gill \& Brar (1981) reported $40{ }^{\circ} \mathrm{C}$ for maximum germination of $T$. monogyna. In $T$. portulacastrum, maximum germination $(90 \%)$ was observed at $35^{\circ} \mathrm{C}$ (Balyan \& Bhan, 1986). Germination of Polygonum persicaria was also higher under high temperatures and maximum germination was observed at $30{ }^{\circ} \mathrm{C}$ (Vleeshouwers, 1998).

Effect of pH: Germination \% of one-year-old $T$. portulacastrum seeds was higher than that of five-year-old seeds at different $\mathrm{pH}$ levels (Figure 1B). Germination \% of both types of seeds was lower under acidic condition than under alkaline or neutral condition. Effect of $\mathrm{pH}$ showed maximum germination \% in alkaline $\mathrm{pH}$ values (8-10). Data shown in Table 2 revealed that germination index was lower while time to $50 \%$ germination and mean germination time were higher in five-year-old seeds than one-year-old seeds. Minimum time to start germination, time to $50 \%$ germination and mean germination time were observed in alkaline $\mathrm{pH}$ values. Germination index was found maximum in $\mathrm{pH} \mathrm{9-10.} \mathrm{This}$ study concluded that an increase in $\mathrm{pH}$ towards alkaline increased germination of T. portulacastrum. Seed germination of Campsis radicans was greater than $60 \%$ over a $\mathrm{pH}$ range from 5 to 9 with higher germination at $\mathrm{pH} 7$ and above (Chachalis \& Reddy, 2000). Germination of Conyza canadensis and Lolium multiflorim was 19 to $36 \%, 37-87 \%$, respectively over a wide range of $\mathrm{pH}$ from 4 to 10 but maximum germination was observed at $\mathrm{pH} 7$ (Nandula et al., 2006, 2009). High seed germination of $T$. portulacastrum over a broad $\mathrm{pH}$ range indicates that $\mathrm{pH}$ is not a limiting factor for germination in most soils.

Drought Stress: An increase in osmotic potential from 0 to $-0.8 \mathrm{MPa}$ decreased germination of $T$. portulacastrum from 100 to 20 and 85.5 to $25 \%$ in one-year-old and fiveyear-old seeds, respectively (Figure 1C).

Table 1 - Effect of temperature $\left({ }^{\circ} \mathrm{C}\right)$ on different germination traits of T. portulacastrum

\begin{tabular}{|l|c|c|c|c|}
\hline \multicolumn{1}{|c|}{ Treatment } & $\begin{array}{c}\text { Time to start } \\
\text { germination (days) }\end{array}$ & $\begin{array}{c}\text { Time to 50\% } \\
\text { germination (days) }\end{array}$ & $\begin{array}{c}\text { Mean germination } \\
\text { time (days) }\end{array}$ & $\begin{array}{c}\text { Germination } \\
\text { index }\end{array}$ \\
\hline Seed age & & & & \\
\hline One-year-old seeds & $1.10 \mathrm{~b}$ & $1.33 \mathrm{~b}$ & $2.05 \mathrm{~b}$ & $9.64 \mathrm{a}$ \\
\hline Five-year-old seeds & $1.80 \mathrm{a}$ & $2.50 \mathrm{a}$ & $3.04 \mathrm{a}$ & $3.62 \mathrm{~b}$ \\
\hline LSD value & 0.22 & 0.26 & & 0.61 \\
\hline Temperature $\left({ }^{\circ} \mathrm{C}\right)$ & & & & \\
\hline 25 & $2.13 \mathrm{a}$ & $2.41 \mathrm{a}$ & $2.96 \mathrm{a}$ & $4.61 \mathrm{~d}$ \\
\hline 30 & $1.75 \mathrm{~b}$ & $2.25 \mathrm{a}$ & $2.82 \mathrm{ab}$ & $5.91 \mathrm{c}$ \\
\hline 35 & $1.38 \mathrm{c}$ & $2.18 \mathrm{a}$ & $2.59 \mathrm{bc}$ & $7.44 \mathrm{ab}$ \\
\hline 40 & $1.00 \mathrm{~d}$ & $1.30 \mathrm{~b}$ & $1.99 \mathrm{~d}$ & $8.21 \mathrm{a}$ \\
\hline 45 & $1.00 \mathrm{~d}$ & $1.44 \mathrm{~b}$ & $2.35 \mathrm{c}$ & $6.95 \mathrm{~b}$ \\
\hline- & 0.35 & 0.41 & 0.29 & 0.96 \\
\hline LSD & & & & \\
\hline
\end{tabular}

A statistical analysis (ANOVA) was made for each treatment and for each column. The values followed by different letters are significantly different at $(p<0.05)$. 
Table 2 - Effect of $\mathrm{pH}$ on different germination traits of T. portulacastrum

\begin{tabular}{|c|c|c|c|c|}
\hline \multicolumn{1}{|c|}{ Treatment } & $\begin{array}{c}\text { Time to start } \\
\text { germination (days) }\end{array}$ & $\begin{array}{c}\text { Time to 50\% } \\
\text { germination (days) }\end{array}$ & $\begin{array}{c}\text { Mean germination } \\
\text { time (days) }\end{array}$ & $\begin{array}{c}\text { Germination } \\
\text { index }\end{array}$ \\
\hline Seed age & & & & \\
\hline One-yearold seeds & 1.00 & $1.28 \mathrm{~B}$ & $1.94 \mathrm{~b}$ & $8.62 \mathrm{a}$ \\
\hline Five-year-old seeds & 1.08 & $2.14 \mathrm{~A}$ & $3.05 \mathrm{a}$ & $4.43 \mathrm{~b}$ \\
\hline LSD value & NS & 0.09 & 0.11 & 0.37 \\
\hline pH levels & & & & $3.66 \mathrm{c}$ \\
\hline 5 & 1.12 & $1.86 \mathrm{ab}$ & $3.42 \mathrm{bc}$ & $3.94 \mathrm{c}$ \\
\hline 6 & 1.12 & $2.00 \mathrm{a}$ & $2.42 \mathrm{bc}$ & $7.41 \mathrm{~b}$ \\
\hline 7 & 1.00 & $1.57 \mathrm{c}$ & $2.26 \mathrm{~cd}$ & $7.59 \mathrm{~b}$ \\
\hline 8 & 1.00 & $1.45 \mathrm{c}$ & $2.21 \mathrm{~d}$ & $8.27 \mathrm{a}$ \\
\hline 10 & 1.00 & $1.59 \mathrm{c}$ & $2.50 \mathrm{~b}$ & $8.30 \mathrm{a}$ \\
\hline LSD & 1.00 & $1.77 \mathrm{~b}$ & 0.19 & 0.64 \\
\hline
\end{tabular}

A statistical analysis (ANOVA) was made for each treatment and for each column. The values followed by different letters are significantly different at $(p<0.05)$.

Germination was completely inhibited at an osmotic potential of - $0.1 \mathrm{MPa}$ in both types of seeds. A three-parameter logistic model \{G (\%) $\left.=99.1 /\left[1+(x /-0.57)^{4.08}\right]\right\}$ showed that an osmotic potential of -0.57 was required for $50 \%$ inhibition of maximum germination of one-year-old seeds (Figure 1C). Similarly, in five-year-old seeds, the fitted model $\{\mathrm{G}(\%)$ $\left.=96.7 /\left[{ }^{1+}(x /-0.55)^{6.08}\right]\right\}$ indicated that the osmotic potential required for $50 \%$ inhibition of maximum germination was $0.55 \mathrm{MPa}$. Drought stress significantly affected the different germination traits of $T$. portulacastrum collected in two different years (Table 3). Germination index was higher in one-year-old seeds while time to start germination, time to $50 \%$ germination and mean germination time were higher in fiveyear-old seeds. Minimum time to start germination $(1.0 \mathrm{~d})$, time to $50 \%$ germination $(1.20 \mathrm{~d})$ and mean germination time $(1.95 \mathrm{~d})$ were observed in the control. When drought stress was increased to $-0.8 \mathrm{MPa}$, time to start germination, time to $50 \%$ germination and mean germination time increased to $2.0 \mathrm{~d}$, $2.03 \mathrm{~d}$ and $2.93 \mathrm{~d}$, respectively. Minimum germination index (1.51) was observed at $0.8 \mathrm{MPa}$ compared with 9.17 in the control (Table 3). This study concluded that an increase in drought stress decreased germination of $T$. portulacastrum. A decrease in water potential gradient between seed and surrounding media adversely affected germination. In other words, water deficit conditions decreased germination because of inadequate water uptake by seeds (Dodd \& Donovan, 1999). Similar results were observed by Nandula et al. (2009) for Lolium multiflorim, whose germination was reduced from 79 to $8 \%$ when drought stress increased from 0 to $0.8 \mathrm{MPa}$. Taisan (2010) reported that drought stress decreased and delayed germination of Pennisetum divisum and germination was only $10 \%$ at drought stress of $-0.8 \mathrm{MPa}$. The significant reduction in germination of T. portulacastrum, even at moderate drought stress levels, is in contradiction to the results of Singh (2009), who reported that moderate stress intensities only delayed germination, whereas the highest concentration of PEG reduced final germination percentages of Sorghum halepense.

Salt Stress: Salinity significantly affected the different germination traits of T. portulacastrum seeds collected in two different years (Figure 1D and Table 4). Germination percentage was higher in oneyear-old seeds than in five-year-old seeds (Figure 1D). Germination \% of one-year-old seeds was higher than $80 \%$ up to $150 \mathrm{mM} \mathrm{NaCl}$ concentration. After this level, germination 
Table 3 - Effect of drought on different germination traits of T. portulacastrum

\begin{tabular}{|c|c|c|c|c|}
\hline Treatment & $\begin{array}{c}\text { Time to start } \\
\text { germination (days) }\end{array}$ & $\begin{array}{c}\text { Time to } 50 \% \\
\text { germination (days) }\end{array}$ & $\begin{array}{l}\text { Mean germination } \\
\text { time (days) }\end{array}$ & $\begin{array}{c}\text { Germination } \\
\text { index }\end{array}$ \\
\hline \multicolumn{5}{|l|}{ Seed age } \\
\hline One-year-old seeds & $1.00 \mathrm{~b}$ & $1.24 \mathrm{~b}$ & $2.38 \mathrm{~b}$ & $6.27 \mathrm{a}$ \\
\hline Five-year-old seeds & $1.85 \mathrm{a}$ & $2.18 \mathrm{a}$ & $2.66 \mathrm{a}$ & $4.30 \mathrm{~b}$ \\
\hline LSD value & 0.13 & 0.04 & 0.13 & 0.22 \\
\hline \multicolumn{5}{|c|}{ Osmotic potential (MPa) } \\
\hline $0($ Control $)$ & $1.00 \mathrm{c}$ & $1.20 \mathrm{~d}$ & $195 \mathrm{c}$ & $9.17 \mathrm{a}$ \\
\hline-0.2 & $1.25 \mathrm{~b}$ & $1.85 \mathrm{~b}$ & $2.41 \mathrm{~b}$ & $7.30 \mathrm{~b}$ \\
\hline-0.4 & $1.37 \mathrm{~b}$ & $1.56 \mathrm{c}$ & $2.51 \mathrm{~b}$ & $6.04 \mathrm{c}$ \\
\hline-0.6 & $1.50 \mathrm{~b}$ & $1.92 \mathrm{~b}$ & $2.80 \mathrm{a}$ & $2.40 \mathrm{~d}$ \\
\hline-0.8 & $2.00 \mathrm{a}$ & $2.03 \mathrm{a}$ & $2.93 \mathrm{a}$ & $1.51 \mathrm{e}$ \\
\hline-1.0 & NG & NG & NG & NG \\
\hline LSD & 0.25 & 0.07 & 0.24 & 0.41 \\
\hline
\end{tabular}

A statistical analysis (ANOVA) was made for each treatment and for each column. The values followed by different letters are significantly different at $(p<0.05)$. NG $=$ not germinated.

Table 4 - Effect of salinity on different germination traits of T. portulacastrum

\begin{tabular}{|c|c|c|c|c|}
\hline Treatment & $\begin{array}{c}\text { Time to start } \\
\text { germination (days) }\end{array}$ & $\begin{array}{c}\text { Time to } 50 \% \\
\text { germination (days) }\end{array}$ & $\begin{array}{l}\text { Mean germination } \\
\text { time (days) }\end{array}$ & $\begin{array}{l}\text { Germination } \\
\text { index }\end{array}$ \\
\hline \multicolumn{5}{|l|}{ Seed age } \\
\hline One-year-old seeds & 2.20 & $2.35 \mathrm{~b}$ & $2.51 \mathrm{~b}$ & $5.74 \mathrm{a}$ \\
\hline Five-year-old seeds & 2.64 & $2.97 \mathrm{a}$ & $3.08 \mathrm{a}$ & $3.92 \mathrm{~b}$ \\
\hline LSD value & NS & 0.04 & 0.03 & 0.18 \\
\hline $\mathrm{NaCl}$ cocentrations $(\mathrm{mM})$ & $1.00 \mathrm{~h}$ & & & \\
\hline $0($ Control $)$ & $1.00 \mathrm{~h}$ & $1.34 \mathrm{j}$ & $1.51 \mathrm{k}$ & $8.98 \mathrm{a}$ \\
\hline 25 & $1.00 \mathrm{~h}$ & $1.45 \mathrm{i}$ & $1.61 \mathrm{j}$ & $8.32 \mathrm{~b}$ \\
\hline 50 & $1.50 \mathrm{~g}$ & $1.79 \mathrm{~h}$ & $1.93 \mathrm{i}$ & $6.51 \mathrm{c}$ \\
\hline 75 & $2.00 \mathrm{f}$ & $2.08 \mathrm{~g}$ & $2.20 \mathrm{~h}$ & $6.47 \mathrm{c}$ \\
\hline 100 & $2.00 \mathrm{f}$ & $2.29 \mathrm{f}$ & $2.41 \mathrm{~g}$ & $6.36 \mathrm{c}$ \\
\hline 125 & $2.00 \mathrm{f}$ & $2.43 \mathrm{e}$ & $2.61 \mathrm{f}$ & $5.46 \mathrm{~d}$ \\
\hline 150 & $3.00 \mathrm{e}$ & $2.95 \mathrm{~d}$ & $3.03 \mathrm{e}$ & $5.21 \mathrm{~d}$ \\
\hline 175 & $3.50 \mathrm{c}$ & $3.02 \mathrm{~d}$ & $3.22 \mathrm{~d}$ & $3.17 \mathrm{e}$ \\
\hline 200 & $3.25 \mathrm{~d}$ & $3.30 \mathrm{c}$ & $3.48 \mathrm{c}$ & $1.99 \mathrm{f}$ \\
\hline 225 & $3.87 \mathrm{~b}$ & $4.09 \mathrm{~b}$ & $4.19 \mathrm{~b}$ & $0.51 \mathrm{~g}$ \\
\hline 250 & $4.56 \mathrm{a}$ & $4.56 \mathrm{a}$ & $4.56 \mathrm{a}$ & $0.14 \mathrm{~g}$ \\
\hline LSD & 0.17 & 0.10 & 0.08 & 0.43 \\
\hline
\end{tabular}

A statistical analysis (ANOVA) was made for each treatment and for each column. The values followed by different letters are significantly different at $(p<0.05)$.

decreased progressively with increased salinity level, and only $10 \%$ germination was observed at the highest level of salinity
(250 mM NaCl concentration). A threeparameter logistic model $\{G(\%)=97.4 /[1+(x /$ $\left.\left.193.8)^{8.9}\right]\right\}$ was fitted to the germination data 
of one year old $T$. portulacastrum seeds (Figure 1D). The model equation showed that germination of one-year-old $T$. portulacastrum seeds was decreased by $50 \%$ of maximum germination at $\mathrm{NaCl}$ concentration of $193.8 \mathrm{mM}$. Similarly, germination of five-yearold seeds decreased with increased $\mathrm{NaCl}$ concentration. According to the fitted model, maximum germination $(71.9 \%)$ occurred at $0 \mathrm{mM}$, and $190 \mathrm{mM} \mathrm{NaCl}$ concentration was required to inhibit $50 \%$ of maximum germination of five-year-old T. portulacastrum seeds (Figure 1D). At different salinity levels, one-year-old and five-year-old seeds have the same time to start germination. Germination index was higher while time to $50 \%$ germination and mean germination time were lower in one-year-old seeds compared with fiveyear-old seeds (Table 4). Minimum time to start germination $(1.0 \mathrm{~d})$, time to $50 \%$ germination $(1.34 \mathrm{~d})$ and mean germination time $(1.51 \mathrm{~d})$ were observed at $0 \mathrm{mM}$. As salinity increased, these germination parameters were increased. Maximum germination index (8.98) was also found in the control, and it was reduced to 0.14 at $250 \mathrm{mM}$. This study concluded that an increase in salinity decreased germination of T. portulacastrum. Decreased germination under salinity could result from the toxic or osmotic effect of $\mathrm{NaCl}$, which prevents seed imbibition (Tobe et al., 1999). Salinity increases the production of ROS (reactive oxygen species) which damage DNA and proteins (Gossett et al., 1994). Chachalis \& Reddy (2000) observed similar results for Campsis radicans in which germination was decreased with increasing salinity levels, and it was only $20 \%$ at $160 \mathrm{mM}$. A decrease in germination with increased salinity has also been reported in Thymus maroccanus Ball by Belaqziz et al. (2009), who observed no germination at $200 \mathrm{mM}$ salinity level. Kaydan \& Yagmur (2008) reported that stress produced by $\mathrm{NaCl}$ delayed germination percentage of triticale. It is assumed that effect of salinity on seed germination depends on weed species.

Field capacity: Emergence of one year old $T$. portulacastrum seeds was higher than fiveyear-old seeds (Figure 2A). When field capacity decreased from 100 to $25 \%$, emergence decreased from 96 to $35 \%$ and 77 to $25 \%$ in one-year-old and five-year-old seeds, respectively. The fitted model $\{E(\%)=96.5 /$ $\left.\left[1+(x / 66.5)^{2.8}\right]\right\}$ showed that field capacity is $66.5 \%$ for $50 \%$ inhibition of the maximum emergence in one-year-old seeds. Model $\{E(\%)$ $\left.=75.5 /\left[1+(x / 64)^{4.2}\right]\right\}$ showed that, in five-yearold seeds, $50 \%$ inhibition of maximum emergence occurred at $64 \%$ field capacity. Emergence index was higher while time to start emergence, time to $50 \%$ emergence and mean emergence time were lower in one-yearold seeds compared with five-year-old seeds (Table 5).The significantly minimum time to start emergence $(2.12 \mathrm{~d})$, time to $50 \%$
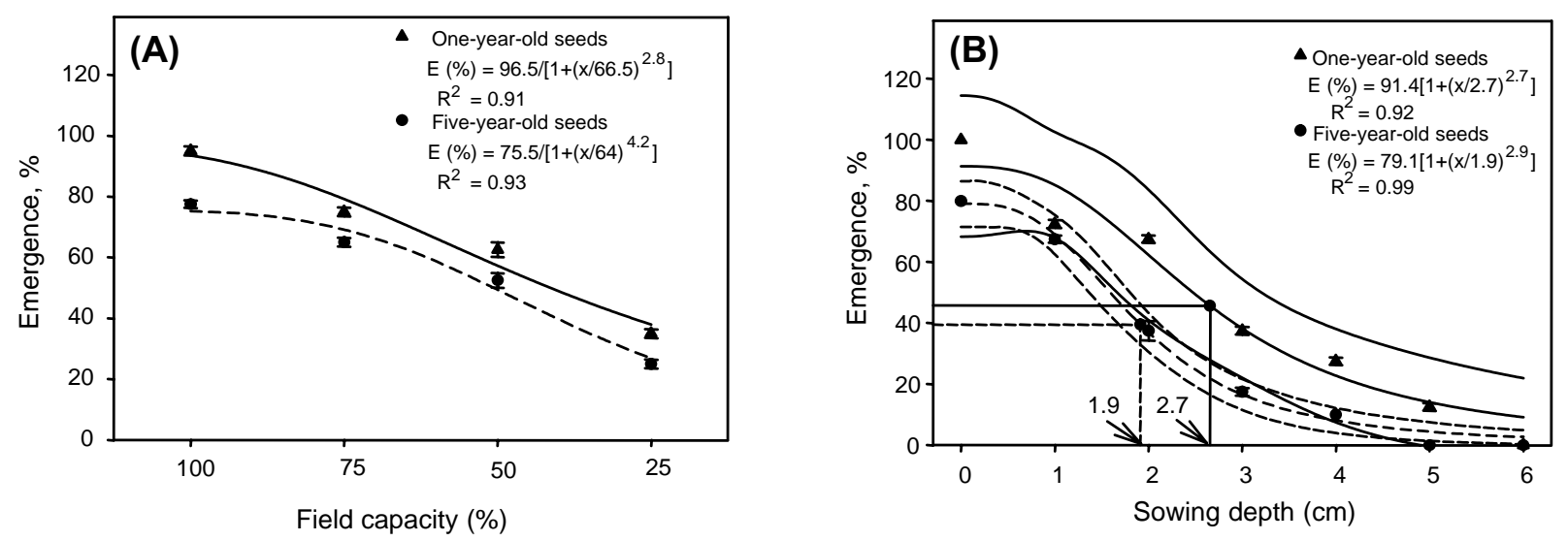

Figure 2 - Effect of field capacity (A) and sowing depth (B) on seed germination of T. portulacastrum. Bold lines represent a threeparameter logistic model fitted to the data for T. portulacastrum, and thin lines in b show $95 \%$ confidence intervals. Continuous lines (_ ) are used for one-year-old seeds and dash lines (- - - ) for five-year-old seeds. Vertical bars represent \pm standard error of the mean if greater than the size of symbol. 
emergence ( $2.62 \mathrm{~d})$, mean emergence time $(2.80 \mathrm{~d})$ and higher emergence index (5.70) were observed at $100 \%$ field capacity. Decrease in field capacity significantly increased time to start emergence, time to $50 \%$ emergence and mean emergence time. The results revealed that emergence of $T$. portulacastrum decreased by decreasing field capacity. The decrease in emergence under low moisture conditions probably happened because there was not enough water for seed imbibition and softening so that seed coats could germinate. Similar results were observed by Hussain et al. (2003) with minimum emergence of Amaranthus viridis at $25 \%$ field capacity and by Laubhan $\&$ Shaffer (2006) with maximum emergence of Cirsium arvense and Lepidium latifolium under 100\% FC. These results are further supported by Aboyami \& Adeyini (2005), who observed that emergence was lower and time to start emergence was higher under $25 \%$ field capacity.

Sowing depth: One-year-old seeds showed higher emergence \% at varying sowing depths compared with of five-year-old seeds. Emergence \% was $<79 \%$ in both types of seeds when placed on soil surface, and it decreased with increased sowing depth (Figure 2B). In five-year-old seeds, no emergence occurred at a sowing depth of $5 \mathrm{~cm}$ or deeper. A threeparameter logistic model was fitted to the seedling emergence data of $T$. portulacastrum collected at two different times. The fitted model estimated that depths of 2.7 and $1.9 \mathrm{~cm}$ were required to inhibit $50 \%$ seedling emergence of maximum seedling emergence in one-year-old and five-year-old seeds, respectively (Figure 2B). Emergence index was higher in one-year-old seeds while time to start emergence, time to $50 \%$ emergence and mean emergence time were lower compared with five-year-old seeds (Table 6). Minimum time to start emergence ( $3.50 \mathrm{~d})$, time to $50 \%$ emergence $(3.75 \mathrm{~d})$, mean emergence time (3.75) were observed in seeds that had been placed on soil surface $(0 \mathrm{~cm})$. These parameters were increased with an increase in sowing depth. Higher emergence index (4.56) was observed in seeds that had been placed on soil surface, and it decreased with increasing depth and was reduced to 0 at $6 \mathrm{~cm}$ (Table 6). This study concluded that increasing sowing depths decreased emergence of $T$. portulacastrum. Lower germination under greater soil depth was due to less vigorous seeds because small seeds have fewer food reserves (Lafond \& Baker, 1986). Reduced emergence may also be due to poor oxygen exchange surrounding the buried seeds (Benvenuti, 2003). Decreased emergence as a result of increased planting depth has also been reported in Caperonia palustris (Koger et al., 2004), in which maximum germination $(67 \%)$ was found on soil surface. Nandula et al.

Table 5 - Effect of field capacity on different emergence traits of T. portulacastrum

\begin{tabular}{|l|c|c|c|c|}
\hline \multicolumn{1}{|c|}{ Treatment } & $\begin{array}{c}\text { Time to start } \\
\text { germination (days) }\end{array}$ & $\begin{array}{c}\text { Time to 50\% } \\
\text { germination (days) }\end{array}$ & $\begin{array}{c}\text { Mean germination } \\
\text { time (days) }\end{array}$ & $\begin{array}{c}\text { Emergence } \\
\text { index }\end{array}$ \\
\hline Seed age & & & & \\
\hline One year old seeds & $3.12 \mathrm{~b}$ & $3.74 \mathrm{~b}$ & $4.01 \mathrm{~b}$ & $4.56 \mathrm{a}$ \\
\hline Five years old seeds & $4.00 \mathrm{a}$ & $4.46 \mathrm{a}$ & $4.68 \mathrm{a}$ & $3.53 \mathrm{~b}$ \\
\hline LSD value & 0.39 & 0.18 & 0.19 & 0.21 \\
\hline Field capacity $(\%)$ & & & & $5.70 \mathrm{a}$ \\
\hline 100 & $2.12 \mathrm{~d}$ & $2.62 \mathrm{~d}$ & $3.80 \mathrm{~d}$ & $4.88 \mathrm{~b}$ \\
\hline 75 & $3.12 \mathrm{c}$ & $3.60 \mathrm{c}$ & $3.74 \mathrm{c}$ & $3.50 \mathrm{c}$ \\
\hline 50 & $4.12 \mathrm{~b}$ & $4.63 \mathrm{~b}$ & $4.81 \mathrm{~b}$ & $2.08 \mathrm{~d}$ \\
\hline 25 & $4.87 \mathrm{a}$ & $5.55 \mathrm{a}$ & $6.05 \mathrm{a}$ & 0.29 \\
\hline LSD & 0.56 & 0.26 & 0.26 & \\
\hline
\end{tabular}

A statistical analysis (ANOVA) was made for each treatment and for each column. The values followed by different letters are significantly different at $(p<0.05)$. 
Table 6 - Effect of sowing depth on different emergence traits of T. portulacastrum

\begin{tabular}{|c|c|c|c|c|}
\hline Treatment & $\begin{array}{c}\text { Time to start } \\
\text { emergence (days) }\end{array}$ & $\begin{array}{c}\text { Time to } 50 \% \\
\text { emergence (days) }\end{array}$ & $\begin{array}{l}\text { Mean emergence } \\
\text { time (days) }\end{array}$ & $\begin{array}{c}\text { Emergence } \\
\text { index }\end{array}$ \\
\hline \multicolumn{5}{|l|}{ Seed age } \\
\hline One-year-old seeds & $4.42 \mathrm{a}$ & $4.10 \mathrm{a}$ & $5.58 \mathrm{a}$ & $2.17 \mathrm{a}$ \\
\hline Five-year-old seeds & $4.00 \mathrm{~b}$ & $4.65 \mathrm{~b}$ & $5.07 \mathrm{~b}$ & $1.43 \mathrm{~b}$ \\
\hline LSD value & 0.20 & 0.23 & 0.23 & 0.12 \\
\hline \multicolumn{5}{|l|}{ Sowing depth $(\mathrm{cm})$} \\
\hline 0 & $3.50 \mathrm{e}$ & $3.75 \mathrm{f}$ & $3.75 \mathrm{~d}$ & $4.56 \mathrm{a}$ \\
\hline 1 & $4.37 \mathrm{~d}$ & $4.81 \mathrm{e}$ & $5.89 \mathrm{c}$ & $3.88 \mathrm{~b}$ \\
\hline 2 & $4.87 \mathrm{c}$ & $5.29 \mathrm{~d}$ & $6.90 \mathrm{ab}$ & $2.43 \mathrm{c}$ \\
\hline 3 & $6.25 \mathrm{~b}$ & $6.18 \mathrm{c}$ & $6.78 \mathrm{~b}$ & $0.93 \mathrm{~d}$ \\
\hline 4 & $6.87 \mathrm{a}$ & $6.65 \mathrm{~b}$ & $6.64 \mathrm{~b}$ & $0.63 \mathrm{e}$ \\
\hline 5 & $3.62 \mathrm{e}$ & $7.47 \mathrm{a}$ & $7.31 \mathrm{a}$ & $0.16 \mathrm{f}$ \\
\hline 6 & $\mathrm{NE}$ & $\mathrm{NE}$ & $\mathrm{NE}$ & $\mathrm{NE}$ \\
\hline LSD & 0.38 & 0.44 & 0.44 & 0.22 \\
\hline
\end{tabular}

A statistical analysis (ANOVA) was made for each treatment and for each column. The values followed by different letters are significantly different at $(P<0.05)$. NE $=$ not emerged.

(2009) observed similar results for Lolium multiflorimin, whose emergence decreased with increasing planting depth, and maximum emergence (80\%) was observed for seeds placed on soil surface. Seeds of Euphorbia heterophylla also showed maximum emergence on soil surface. Moreover, seeds emerged earlier at 1-2 $\mathrm{cm}$ depth than at $5 \mathrm{~cm}$ depth or deeper (Etejere \& Okoko, 1989).

This study concluded that different ecological factors such as temperature, salinity, drought, field capacity, $\mathrm{pH}$ and sowing depth play an important role in germination of $T$. portulacastrum, which has potential to germinate/emerge under varying ecological conditions. This study will be helpful in predicting suitable environments for germination of this weed, thus making it much easier to prevent the weed from spreading into new areas.

\section{LITERATURE CITED}

ABOYAMI, Y. A.; ADEYINI, A. M. Comparative germination responses of cowpea and maize genotypes of soil moisture content. Agrosearch., v. 7, n. 1-2, p. 34-42, 2005.

ASSOCIATION OF OFFICIAL SEED ANALYSIS - AOSA. Rules for testing seeds. J. Seed Sci. Technol., v. 12, n. 1, p. $1-112,1990$
BALYAN, R. S.; BHAN, V. M. Germination of horse purslane (Trianthema portulacastrum) in relation to temperature, storage conditions and seeding depths. Weed Sci., v. 34, n. 4, p. 513-515, 1986

BARTLETT, M. S. The use of transformations. Biometrics, v. 3, n. 1, p. 39-52, 1947.

BELAQZIZ, R. et al. Salt stress effect on germination, growth and essential oil content of Endemic thyme species in morocco (Thymus maroccanus ball.). J. Appl. Sci. Res., v. 5, n. 7, p. 858-863, 2009.

BENVENUTI, S. Soil texture involvement in germination and emergence of buried weed seeds. J. Agron., v. 95, n. 1, p. 191-198, 2003.

CHACHALIS, D.; REDDY, K. N. Factors affecting Campsis radicans seed germination and seedling emergence. Weed Sci., v. 48 , n. 2 , p. $212-216,2000$

COOLBEAR, P. et al. The effect of low temperature presowing treatment on the germination performance and membrane integrity of artificially aged tomato seeds. J. Exper. Bot., v. 35, n. 11, p. 1609-1617, 1984.

DAS, T. K. Basics and applications. New Delhi: Jain Brothers, 2008. 901 p.

DODD, G. L.; DONOVAN, L. A. Water potential and ionic effects on germination and seedling growth of two cold desert shrubs. Am. J. Bot., v. 86, n. 8, p. 1146-1153, 1999. 
ELLIS, R. A.; ROBERTS, E. H. The quantification of aging and survival in orthodox seeds. Seed Sci. Technol., v. 9, n. 2, p. $373-409,1981$.

ETEJERE, E. O.; OKOKO, T. O. Seed production, germination and emergence of Euphorbia heterophylla $\mathrm{L}$. Nigerian J. Bot., v. 2, n. 1, p. 143-147, 1989

GILL, H. S.; BRAR, L. S. The growth and development of T. monogyna under self induced competition. Indian J. Ecol., v. 8, n. 2 , p. $213-216,1981$.

GOSSETT, D. R. et al. Antioxidants response to $\mathrm{NaCl}$ stress in salt tolerant and salt sensitive cultivars of cotton (Gossypium hirsutum L.). Crop Sci., v. 34, n. 3, p. 706-714, 1994.

HAZRA, D. et al. Interference and economic threshold of horse purslane (Trianthema portulacastrum) in soybean cultivation in northern India. Weed Biol. Manag., v. 11, n. 2, p. $72-82,2011$

HOSSAIN, M. A. et al. Influence of temperature levels and planting time on sprouting of rhizome-bud and biomass production of torpedo grass (Panicum repens L.) in Okinawa Island, southern Japan. Weed Biol. Manag., v. 1, n. 3, p. 164-169, 2001.

HUSSAIN, F. et al. Some auto ecological studies on Amaranthus viridis L. Pakistan J. Weed Sci. Res., v. 9, n. 12 , p. $117-124,2003$

JAMIL, M. et al. Salinity reduced growth PS2 photochemistry and chlorophyll content in radish. Agric. Sci., v. 64, n. 2, p. 111-118, 2007.

KAYA, M. D. et al. Seed treatments to overcome salt and drought stress during germination in sunflower (Helianthus annuиs L.). Eur. J. Agron., v. 24, n. 4, p. 291-295, 2006.

KAYDAN, D.; YAGMUR, M. Germination, Seedling growth and relative water content of shoot in different seed sizes of Triticale under osmotic stress of water and $\mathrm{NaCl}$. Afr. $\mathbf{J}$. Biotechnol., v. 7, n. 16, p. 2862-2868, 2008.

KOGER, C. H. et al. Factors effecting seed germination, seedling emergence and survival of texa weed (Caperonia palustris). Weed Sci., v. 52, n. 6, p. 989-995, 2004.

LAFOND, G. P.; BAKER, R. J. Effects of genotype and seed size on speed of emergence and seedling vigor in nine spring wheat cultivars. Crop Sci., v. 26, n. 2, p. 341-346, 1986.

LAUBHAN, M. K.; SHAFFER, T. L. Seed germination of Cirsium arvense and Lepidiu mlatifolium: implications for management of montane wetlands. Wetlands, v. 26, n. 1, p. $69-78,2006$
NANDULA, V. K. et al. Seed germination difference between glyphosate resistant and susceptible Italian ryegrass population. Weed Technol., v. 31, n. 2, p. 123-133, 2009

NANDULA, V. K. et al. Factors affecting germination of horseweed (Conyza Canadensis). Weed Sci., v. 54, n. 5, p. 898-902, 2006.

RAMIREZ, A. H. et al. Germination and emergence characteristics of common beggar's-tick (Bidens alba). Weed Sci., v. 60, n. 3, p. 374-378, 2012.

$\mathrm{RAO}, \mathrm{N}$. et al. Influence of environmental factors on seed germination and seedling emergence of American sloughgrass (Bechmannia syzigachne). Weed Sci., v. 56, n. 4, p. 529-533, 2008.

SAEED, M. et al. Interference of horse purslane (Trianthema portulacastrum L.) with maize (Zea mays L.) at different densities. Pakistan J. Bot., v. 42, n. 1, p. 173-179, 2010.

\section{STATISTICAL ANALYSIS SYSTEMS - SAS. SAS} procedures guide. version 9. Cary, Statistical Analysis Systems Institute, 2002.

SENTHIL, A. et al. Identification of threshold level of horse purslane (Trianthema portulacastrum) in irrigated cowpea (Vigna unguiculata). Indian J. Crop Sci., v. 4, n. 1, p. 141-143, 2009.

SINGH, S. Effect of temperature and water potential on germination of twelve weed species. Indian J. Weed Sci., v. 41, n. 3-4, p. 113-126, 2009.

STEEL, R. G. D. et al. Principles and procedures of statistics. 3.ed. New York: McGraw Bill Book, 1997. p. $178-198$

STEUTER, A. A. et al. Water potential of aqueous polyethylene glycol. Plant Physiol., v. 67, n. 1, p. 64-67, 1981.

TAISAN, W. A. Competitive effects of drought and salt stress on germination and seedling growth of Pennisetum divisum (Gmel) Henr. Am. J. Appl. Sci., v. 7, n. 5, p. $640-646,2010$.

TOBE, $\mathrm{K}$. et al. Effect of $\mathrm{NaCl}$ on seed germination of five non halophytic species from a Chinese desert environment. Seed Sci. Technol., v. 27, n. 2, p. 851-863, 1999.

UNGAR, I. Ecophysiology of vascular halophytes. Boca Raton: CRC Press, 1991. p. 209.

VLEESHOUWERS, L. M. The effect of seed dormancy on percentage and rate germination in Polygonum persicaria, and its relevance for crop-weed interaction. Ann. Appl. Biol., v. 132 , n. 2 , p. 289-299, 1998. 